\title{
Effects of Captopril on the Hypertrophied Heart of Essential Hypertensive Patients
}

\author{
Youichiro FURUnO', Yasuhide NAKASHIMA', Masasuke FujITA', \\ Ryouji SAKO ${ }^{2}$ and Akio KUROIWA \\ 'Second Department of Internal Medicine, School of Medicine, University of Occupational \\ and Environmental Health Japan. Kitakyushu 807, Japan \\ ${ }^{2}$ Internal Medicine, Nippon Steal Corporation, Yawata Works Hospital. Kitakyushu 805, Japan
}

\begin{abstract}
Changes in blood pressure and heart rate after exercise, left ventricular wall thickness, ejection fraction and left ventricular mass were examined by echocardiography before and at the 8th week administration of captopril $(37.5-75.0 \mathrm{mg} / \mathrm{day})$ in 11 patients with essential hypertension. The blood pressure showed a gradual and significant decrease from the second week of captopril administration, but the heart rate remained unchanged. No changes were observed in the blood pressure or heart rate after exercise, nor before, during and after the administration of captopril. In the echocardiographic examinations, the wall thickness decreased significantly from $12.1 \pm 2.1 \mathrm{~mm}$ before administration to $10.6 \pm 1.5 \mathrm{~mm}$ at the 8 th week of administration in the interventricular septum, from $11.2 \pm 1.8 \mathrm{~mm}$ to $10.1 \pm 1.5 \mathrm{~mm}$ in the left ventricular posterior wall, and the left ventricular mass in parallel decreased from $266 \mathrm{~g}$ to $218 \mathrm{~g}$. In 7 patients, whose wall thickness was $12 \mathrm{~mm}$ or more, the thickness of the septum decreased significantly from $13.9 \pm 1.2 \mathrm{~mm}$ to $11.7 \pm 2.1 \mathrm{~mm}$ and that of the left ventricular posterior wall from $12.6 \pm 1.5 \mathrm{~mm}$ to $10.6 \pm 1.8 \mathrm{~mm}$. Captopril administration produced regression of cardiac hypertrophy in patients with essential hypertension within a period of only 8 weeks.
\end{abstract}

Key words : : captopril, ACE inhibitor, essential hypertension, hypertrophied heart.

(Received 10 July 1990, accepted 27 September 1990)

\section{Introduction}

In the treatment of hypertensive patients, we can now select drugs from many antihypertensive agents that are best suited for the different reguirements of individual patients. In treating hypertension complicated by left ventricular hypertrophy, it is important to administer antihypertensive agents that also reduce hypertensive cardiac hypertrophy. Such drugs include $\alpha$-methyl dopa (Fouad et al., 1982; Sen, 1983), $\beta$-blocking agents (Ibrahim et al., 1981; Wikstrand et al., 1983; Kaul et al., 1984; Dunn et al.,1987), calcium (Ca) antagonists (Strauer et al., 1984; Sheiban et al., 1987), $\beta$-blocking agents (Leenen et al., 1987), and angiotensin converting enzyme (ACE) inhibitors (Lambardo et al., 1983; Mujaris et al., 1983; Nakashima et al., 1984; Dunn et al., 1984; Sheiban et al., 1987).

In this study, we administered captopril, an ACE inhibitor, to patients with essential hypertension, and examined changes in blood pressure and heart rate after exercise. In 
addition, the left ventricular wall thickness and left ventricular mass (LVM) were determined by echocardiography. This study demonstrated that cardiac hypertrophy can be reversed by an 8-week treatment with captopril.

\section{Methods}

Patients: The patients included males and females aged 37 to 67 years (Mean \pm SD of 54.7 years) whose systolic blood pressure was $160 \mathrm{mmHg}$ and above, or diastolic pressure was 95 $\mathrm{mmHg}$ or above during a 4-week observation period. The severity of hypertension in these patients was WHO grades I and II unaccompanied by severe organic disorders. Patients with secondary hypertension, malignant hypertension, or marked kidney or liver disorders were excluded. Patients who had been given antihypertensive agents other than the ACE inhibitors were included in the study insofar as they fulfilled the above criteria and they continued taking their previous medication (Table 1).

Administration: All the patients were given captopril at a dose of $37.5 \mathrm{mg} /$ day for 4 weeks as an intial dose and then it was increased to $75 \mathrm{mg}$ if a sufficient reduction in the blood pressure had not been obtained. The blood pressure and heart rate were determined every 2 weeks. Patients in whom continuation of the protocol was considered to be inappropriate for any reason were excluded from evaluations.

Echocardiographic examination: The thickness of the left ventricular posterior wall (LVPW), the interventricular septum (IVS), and systolic and diastolic left ventricular internal dimensions (LVID) were determined by echocardiography before and after the 8-week treatment with captopril. Echocardiography and the measurement determinations were carried out by

Table 1. Background of patients

\begin{tabular}{ccccccc}
\hline $\begin{array}{c}\text { Patient } \\
\text { No. }\end{array}$ & Sex & Age & $\begin{array}{c}\text { Blood pressure } \\
\text { before treatment }\end{array}$ & $\begin{array}{c}\text { WHO } \\
\text { stage }\end{array}$ & $\begin{array}{c}\text { Dose of } \\
\text { captopril }\end{array}$ & $\begin{array}{c}\text { Concomitant } \\
\text { medication }\end{array}$ \\
\hline 1 & M & 52 & $172 / 102$ & I & 75 & diuretic \\
2 & F & 63 & $200 / 104$ & II & 75 & - \\
3 & M & 49 & $178 / 112$ & II & 75 & - \\
4 & M & 62 & $146 / 72^{*}$ & II & 37.5 & $\beta$-blocker, Ca-antagonist \\
5 & M & 55 & $138 / 86^{*}$ & I & 37.5 & diuretic, Ca-antagonist \\
6 & F & 57 & $156 / 108$ & II & 37.5 & Ca-antagonist \\
7 & F & 37 & $168 / 110$ & II & 75 & - \\
8 & F & 67 & $150 / 92$ & II & 37.5 & diuretic \\
9 & M & 55 & $142 / 100$ & II & 75 & - \\
10 & M & 49 & $160 / 110$ & II & 37.5 & - \\
11 & M & 47 & $180 / 96$ & II & 37.5 & - \\
\hline
\end{tabular}

* Blood pressure was over $160 \mathrm{mmHg}$ in systole or $95 \mathrm{mmHg}$ in diastole before the administration of other drugs ( $\beta$-blocker, Ca-antagonist or diuretics) 
doctors or technicians who had not been informed of this study. The ejection fraction was calculated by the method of Teichholz, and left ventricular mass (LVM) by the formula, $\mathrm{LVM}=1.05$ (LVID + IVS + LVPW $)^{3}$, according to the method of Devereux \& Reichek (1977).

Exercise test: Blood pressure and heart rate were determined at the time of the echocardio-<smiles>COOCOOCOOCOOCOOC(C)OOC</smiles>
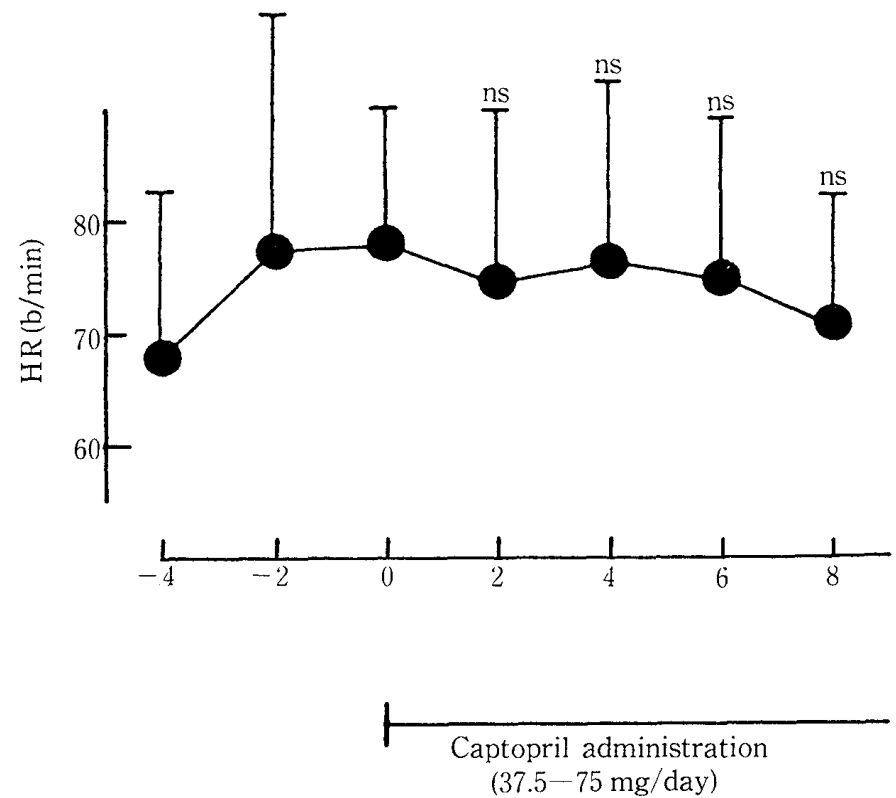

Fig. 1. Sequential changes in resting blood pressures and heart rate $(n=11)$. $* P<0.05$ as compared with control (0 week). 
graphic examinations before and at the 8th week administration of captopril. The same exercise load was applied on a treadmill.

\section{Results}

According to the criteria by WHO, the severity of hypertension was grade I in 2 patients and grade II in 9 patients. Five patients had received other antihypertensive medication before the administration of captopril, but 6 patients had not received any antihypertensive medication before it was administrated. As for concomitant drugs, diuretics were used in 2 patients, Ca antagonists in 1 patient, $\beta$-blockers $+\mathrm{Ca}$ antagonists in 1 patient, and diuretics plus $\mathrm{Ca}$ antagonists in 1 patient. The final captopril dose was 37.5 $\mathrm{mg} /$ day in 6 patients and $75 \mathrm{mg} /$ day in 5 patients.

Figure 1 shows the effects of captopril on blood pressure and heart rate. The systolic and diastolic blood pressures just before the captopril administration were $163 \pm 19 \mathrm{mmHg}$ and $99 \pm 12 \mathrm{mmHg}$, respectively and the heart rate was $78 \pm 13$ beats/min. After 2 weeks of captopril administration, both the systolic and diastolic blood pressures decreased significantly $(P<0.05)$ as compared with those before captopril administration, but no significant changes were observed in the heart rate. After 8 weeks of captopril administration, both the systolic and diastolic blood pressures remained significantly decreased, and the heart rate unchanged. Sympton-limited treadmill exercise tests were performed before and at the 8th week of captopril administration. Blood pressure and heart rate were determined before and after exercise. The method and the strength of the exercise were the same at both times. As shown in Table 2, only the systolic blood pressure with captopril administration was lower before exercise. There were no differences in other parameters.

Echocardiography was performed before and at the 8th week of captopril administration. In all 11 patients, the wall thickness decreased significantly $(P<0.05)$ from $12.1 \pm 2.1$ $\mathrm{mm}$ for the IVS and $11.2 \pm 1.8 \mathrm{~mm}$ for the LVPW before captopril administration to 10.6 $\pm 2.0 \mathrm{~mm}$ and $10.1 \pm 1.5 \mathrm{~mm}$, respectively, at 8th week of captopril administration

Table 2. Changes in blood pressure and heart rate with and without captopril (Exercise test)

\begin{tabular}{lcrr}
\hline & Before exercise & After exercise & Mean difference \\
\hline Without captopril & & & \\
systolic BP $(\mathrm{mmHg})$ & $163.3 \pm 14.5$ & $189.7 \pm 24.9$ & 26.4 \\
diastolic BP (mmHg) & $97.3 \pm 12.5$ & $100.3 \pm 10.0$ & 3.0 \\
heart rate (bpm) & $69.6 \pm 8.3$ & $109.3 \pm 18.2$ & 39.4 \\
With captopril (week 8$)$ & & & 36.9 \\
systolic BP (mmHg) & $151.4 \pm 17.2^{*}$ & $188.3 \pm 29.0$ & 8.2 \\
diastolic BP (mmHg) & $93.1 \pm 12.5$ & $104.3 \pm 19.9$ & 37.7 \\
heart rate (bpm) & $64.6 \pm 5.3$ & & \\
\hline (Mean $\pm \mathrm{SD})(\mathrm{n}=11)$ & & &
\end{tabular}



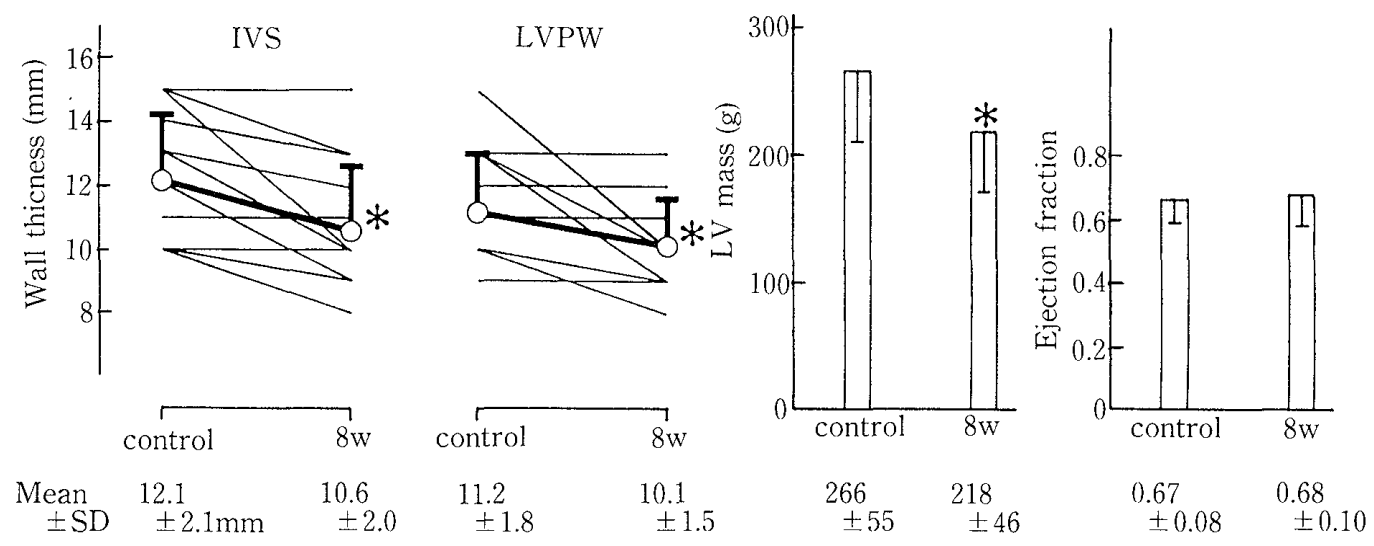

Fig. 2. Comparisons of echocardiographic measurements before and after captopril administration. $* P<0.05$

(Fig. 2). The LVM calculated by the method of Devereux decreased significantly $(P<0.05)$ from $266 \pm 55 \mathrm{~g}$ before captopril administration to $218 \pm 46 \mathrm{~g}$ at the 8th week of administration. There were no significant changes in the ejection fraction (EF) with or without captopril administration.

\section{Discussion}

Cardiac hypertrophy is a representative complication of hypertension. However, its pathogenesis cannot be explained by pressure overload alone, and a number of factors including catecholamines, the renin-angiotensin system, obesity, aging, and genetic factors are thought to be involved.

Cardiac hypertrophy is considered to be an adjustment of the myocardium to pressure overload in order to maintain the stress of the left ventricular wall at a uniform level at the expense of its dilating ability. However, stress of the left ventricular wall and cardiac hypertrophy do not necessarily occur simultaneously, and the degree of cardiac hypertrophy varies greatly.

The incidence of cardiovascular diseases (coronary disease, stroke, heart failure, obstructive diseases of peripheral arteries, etc.) increases in the presence of cardiac hypertrophy (Kannel, 1983; Casale et al., 1986). Sudden death is also known to occur more frequently in patients with cardiac hypertrophy. Ventricular arrhythmias may mediate between cardiac hypertrophy and sudden death (Messerli et al., 1984). In addition, it has been suggested that coronary reserve is related to coronary perfusion pressure to the myocardial mass (Wicker et al., 1983; Kobayashi et al., 1984), and the cardiac reserve is considered to decrease with coronary perfusion pressure, which decreases due to antihypertensive therapy, unless the myocardial mass is also reduced. For this reason, the reduction of cardiac hypertrophy is considered to be advantageous for the prevention of ischemic heart disease (Wicker \& Tarazi, 1982). The management of cardiac hypertrophy is considered to be an important objective of antihypertensive therapy along with normaliza- 
tion of blood pressure (Tarazi \& Fouad, 1985).

A considerable number of antihypertensive agents have been shown to be effective against cardiac hypertrophy. Among them, $\alpha$-methyl dopa produces the most reliable and quickest anticardiotrophic effect, but several recent reports have indicated that ACE inhibitors have comparable effects against cardiac hypertrophy. Although there has been no consensus concerning the effects of $\beta$-blockers on cardiac hypertrophy, recently they are considered to reduce it. However, the effect of $\beta$-blockers is relatively slow according to a number of reports (Ibrahim et al., 1981; Wikstrand et al., 1983; Kaul et al., 1984; Dunn et al., 1987). Similarly, Ca antagonisits are considered to be relatively slow-acting anticardiotrophic agents. The anticardiotrophic effect of thiazide antihypertensive diuretics is considered to be slow and weak.

This study was performed to clarify the effects of ACE inhibitors on cardiac hypertrophy, which have not been thoroughly investigated in Japan. We observed regression of cardiac hypertrophy in patients with essential hypertension after administration of captopril for only 8 weeks. These results were similar to those of the study of Lambardo et al. (1983).

In six patients, the thickness of the IVS and LVPW decreased significantly. As for individual patients, the wall thickness decreased by $2 \mathrm{~mm}$ or more in the IVS or LVPW in 5 of the 7 patients with cardiac hypertrophy and in 1 of the 4 patients without cardiac hypertrophy.

Captopril was administered at a dose of $37.5 \mathrm{mg} /$ day in 6 patients and at $75 \mathrm{mg} /$ day in 5 patients. The wall thickness decreased by $2 \mathrm{~mm}$ or more in all 5 patients receiving 75 $\mathrm{mg} /$ day. Of the 6 patients receiving captopril at a dose of $37.5 \mathrm{mg} /$ day, 3 patients, received other drugs and the effects of these concomitant drugs must be considered. Of the 3 patients treated with only captopril at a dose of $37.5 \mathrm{mg} /$ day, the wall thickness decreased by $2 \mathrm{~mm}$ or more in 1 patient but did not decrease in another patient with cardiac hypertrophy, and the remaining patient did not show cardiac hypertrophy. Therefore, the expected effect for regression of hypertrophy in cardiac muscles was seen in all but one patient.

Of the 5 patients given captopril with other drugs, 3 patients had received Ca antagonists or $\beta$-blockers for several months before the initiation of the captopril therapy. One of these 3 patients had cardiac hypertrophy, but the other 2 patients did not. None of them showed a reduction in the wall thickness. The wall thickness decreased by $2 \mathrm{~mm}$ or more in both of the remaining 2 patients who were given hypotensive diuretics. In the 6 patients given captopril alone, the wall thickness decreased by $2 \mathrm{~mm}$ or more in all 3 patients with cardiac hypertrophy. These results suggest that, in the patients who had been given Ca antagonists and $\beta$-blockers, the effects of these agents on hypertrophy in cardiac muscles had already appeared before the captopril administration, and that cardiac hypertrophy is not reduced by captopril alone. However, this finding must be studied in a larger group of patients. 


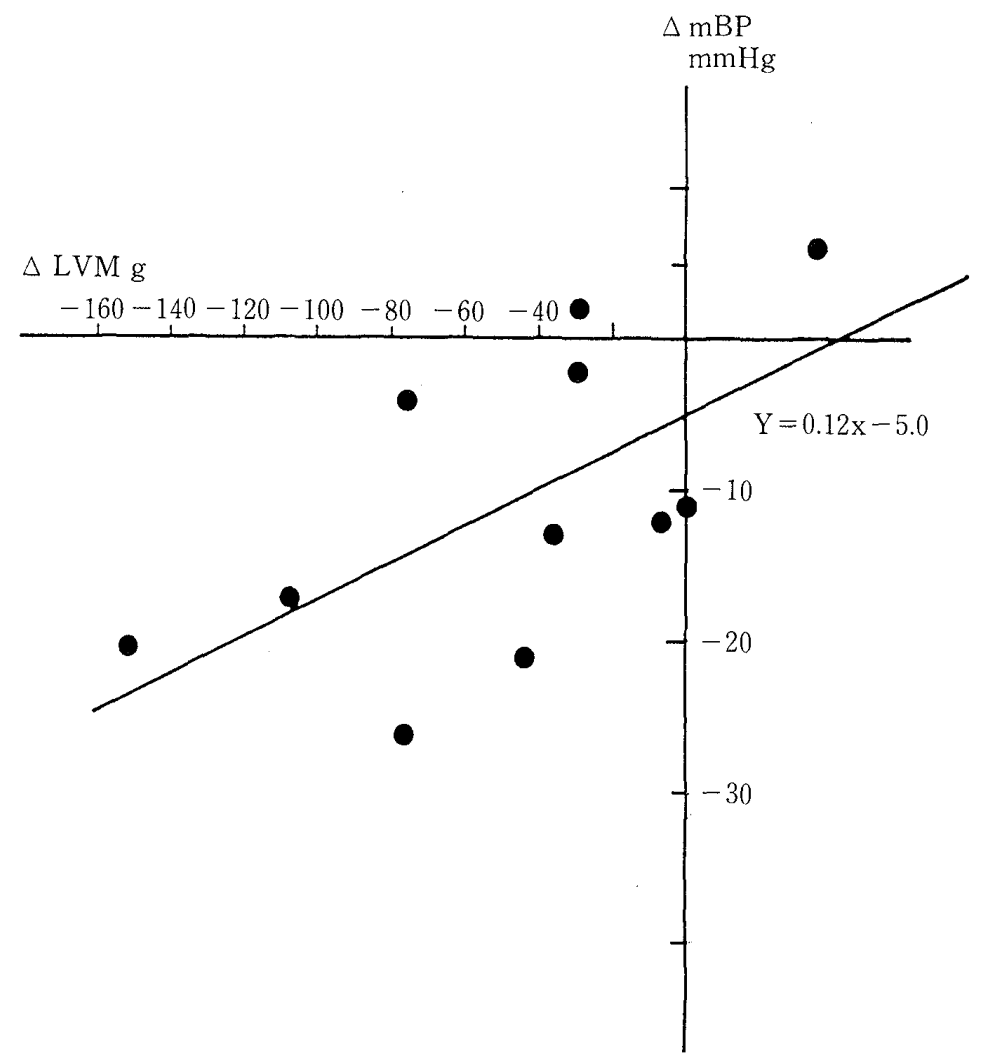

Fig. 3. Relationship between the decrease in blood pressure and changes in left ventricular mass. $\mathrm{n}=11, \quad \mathrm{r}=0.62, \quad * P<0.05$

There was no clear relationship between the regression of cardiac hypertrophy and the WHO staging or the duration of hypertension. The relationship between the regression of cardiac hypertrophy and blood pressure or heart rate during exercise was excluded by the absence of changes in blood pressure or heart rate before and after captopril administration.

A number of studies have indicated that the degree of the reduction in blood pressure is not related, or only slightly related, to the degree of regression of cardiac hypertrophy (Drayer et al., 1983; Nakashima et al., 1984). We also noted a very weak correlation between the reduction in blood pressure and changes in the LVM (Fig. 3).

Concerning the changes in cardiac function associated with the regression of cardiac hypertrophy, a number of studies have suggested that regression of cardiac hypertrophy occurs without deterioration of the cardiac function (Drayer et al., 1983; Nakashima et al., 1984; Tarazi \& Fouad, 1985.) The percent reduction in the LVID and left ventricular systolic stress must be evaluated for the assessment of the left heart function. However, we determined EF alone in this study and observed no change in it before and after captopril administration.

In summary captopril administration at a dose of $37.5-75.0 \mathrm{mg} /$ day produced a regression of cardiac hypertrophy in patients with essential hypertension within a period of only 8 weeks. 


\section{References}

Casale, P. N., Devereux, R. B., Milner, M. et al. (1986): Value of cchocardiographic measurement of left ventricular mass in predicting cardiovascular morbid events in hypertensive men. Ann. Intern. Med., 105: $173-178$.

Devereux, R. B. \& Reichek, N. (1977): Echocardiographic determination of left ventricular mass in man. Circulation, 55: 613-618.

Drayer, I. M., Weber, M. A., Gardin, J. M. et al. (1983): Effect of long-term antihypertensive therapy on cardiac anatomy in patients with essential hypertension. Am. J. Med., 75 (Suppl. 3A): 116-120.

Dunn, F. G., Oigman, W., Ventura, H. O. et al. (1984): Enalapril improves systemic and renal hemodynamics and allows regression of left ventricular mass in essential hypertension. Am. J. Cardiol., 53: 105108.

Dunn, F. G., Ventura, H. O., Messerli, F. H. et al. (1987): Time course of regression of left ventricular hypertrophy in hypertensive patients treated with atenorol. Circulation, 76: 254-258.

Fouad, F. M., Nakashima, Y., Tarazi, R. C. et al. (1982): Reversal of left ventricular hypertrophy in hypertensive patients treated with methyldopa. Am. J. Cardiol., 49: 795-801.

Ibrahim, M. M., Madkour, M. A. \& Mossallam, R. (1981): Factors influencing cardiac hypertrophy in hypertensive patients. Clin. Sci., 61: 105S-108S.

Kannel, W. B. (1983): Prevalence and natural history of electrocardiographic left ventricular hypertrophy. Am. J. Med., 75 (Suppl. 3A): 4-11.

Kaul, U., Mohan, J. C. \& Bhatia, M. L. (1984): Effects of labetalol on left ventricular mass and function in hypertension - an assessment by serial echocardiography. Int. J. Cardiol., 5: 461-469.

Kobayashi, K., Tarazi, R. C., Lovenberg, W. et al. (1984): Coronary blood flow in genetic cardiac hypertrophy. Am. J. Cardiol., 53: 1360-1364.

Lambardo, M., Zaini, G., Pastori, F. et al. (1983): Left ventricular mass and function before and after antihypertensive treatment. J. Hypertension, 1: 215-219.

Leenen, F. H. H., Smith, D. L., Farkas, R. M. et al. (1987): Vasodilators and regression of left ventricular hypertrophy. Am. J. Med., 82: 969-978.

Messerli, F. H., Ventura, H. O., Elizardi, D. J. et al. (1984): Hypertension and sudden death. Am. J. Med., 77: 18-22.

Mujais, S. K., Fouad, F. M. \& Tarazi, R. C. (1983): Reversal of left ventricular hypertrophy with captopril; heterogeneity of response among hypertensive patients. Clin. Cardiol., 6: 595-602.

Nakashima, Y., Fouad, F. M. \& Tarazi, R. C. (1984): Regression of left ventricular hypertrophy from systemic hypertension by enalapril. Am. J. Cardiol., 53: 1044-1049.

Sen, S. (1983): Regression of cardiac hypertrophy - Experimental animal model. Am. J. Med., 75(3A): $87-93$.

Sheiban, I., Arcaro, G., Covi, G. et al. (1987): Regression of cardiac hypertrophy after antihypertensive therapy with nifedipine and captopril. J. Cardiovasc. Pharmacol., 10 (Suppl. 10): S187-S191.

Strauer, B. E., Mahmoud, M. A., Bayer, F. et al. (1984): Reversal of left ventricular hypertrophy and improvement of cardiac function in man by nifedipine. Eur. Heart J., 5 (Suppl. F): 53-60.

Tarazi, R. C. \& Fouad, F. M. (1985): Reversal of cardiac hypertrophy by medical treatment. Ann. Rev. Med., 36: 407-414.

Wicker, P. \& Tarazi, R. C. (1982): Coronary blood flow in left ventricular hypertrophy. Eur. Heart J., 3 (Suppl. A): $111-118$.

Wicker, P., Tarazi, R. C. \& Kobayashi, K (1983): Coronary blood flow during the development and regression of left ventricular hypertrophy in renovascular hypertensive rats. Am. J. Cardiol., 51: 17441749 .

Wikstrand, J., Trimarco, B., Buzzetti, G. et al. (1983): Increased cardiac output and lowered peripheral resistance during metoprolol treatment. Acta Med. Scand., 672 (Suppl.): 105-110. 
本態性高血圧症の肥大心に対するカプトプリルの効果

古野陽一郎 ${ }^{1} \cdot$ 中島 康秀 ${ }^{1}$ 藤田 政介 ${ }^{1} \cdot$ 迫 良治 ${ }^{2} \cdot$ 黑岩 昭夫

産業医科大学第二内科学教室

2新日鉄八幡製鉄所病院内科

要 旨： 本態性高血压症患者にカプトプリル 37.5-75.0 mg/日を投与し, 投与前と投与後8週とで, 運動負荷後血圧，脈拍，心エコー検査による変化を検討した。心エコー検查が正確に記録 できた症例は 11 例（男性7例，女性4例，平均年令55才）で，他の降圧薬で効果不十分な 例 (併用例) 5例，単独例6例であった．安静時血圧はカプトプリル投与後第2週より有意 に低下し心拍数は変化しなかった。投与前と投与後第8週に行われた運動負荷で，負荷後 の血压，脈拍は，カプトプリル投与前後で変化しなかった。 カプトプリル投与前と投与8 週目の心エコー検査では，心室中隔は $12.1 \pm 2.1 \mathrm{~mm}$ から $10.6 \pm 2.0 \mathrm{~mm}$ 八，左室後壁 は $11.2 \pm 1.8 \mathrm{~mm}$ から $10.1 \pm 1.5 \mathrm{~mm}$ へと有意に減少した。特に，肥大心（壁厚>12 $\mathrm{mm}$ ）を有する7例では，心室中隔は $13.9 \pm 1.2 \mathrm{~mm}$ から $11.7 \pm 2.1 \mathrm{~mm}$ へと有意に減 少し, 左室後壁は $12.6 \pm 1.5 \mathrm{~mm}$ から $10.6 \pm 1.8 \mathrm{~mm}$ と有意に減少した.

J. UOEH（産業医大誌）, $12(4): 379-387(1990)$ 